\title{
Exploiting the Social Fabric of Networks: A Social Capital Analysis of Historical Financial Frauds
}

\section{Introduction}

In 1920 Federal Judge Clarence Hale sentenced Carlo Ponzi to 5 years in prison for running a pyramid, 'rob Peter to pay Paul' scheme (1). On hearing the verdict Ponzi turned to one of the assembled journalists and handed him a hastily scribbled note, 'transit gloria mundi', which can be translated as: 'thus passes worldly glory’ (Zuckoff 2006, 290). The swindler's infamy endured to the extent that ninety years later in 2010, when Federal Judge Denis Chin sentenced another egregious fraudster, Bernie Madoff to a 150-year prison sentence, he invoked the earlier fraudsters name to describe the con; declaring that Madoff had been running a 'Ponzi Scheme'. On hearing his sentence Madoff also made a histrionic gesture, with eyes welling, he mouthed an apparently heartfelt, 'I'm sorry' to the assembled court, who it was reported were deeply unimpressed (Arvelund 2009, 277). Further echoing the Ponzi case, a new verb was coined, 'to be Madoffed': meaning 'to be cheated', and one can speculate on whether this newly minted neologism will gain the same currency as Ponzi's contribution to the syntax of criminality.

The contention of this article is that Madoff and Ponzi share more than a dramatic court scene, rather they are both examples of a type of white-collar criminal who exploit the resources that inhere in social relationships to commit their crimes. The recurrence of whitecollar crime, (2) including affinity frauds (Perri and Brody 2011: 46) and financial/financial frauds (Payne, 201: 243-259), suggests that accounts that concentrate on fleeting circumstances are incomplete. (3) In response, this article will make the case that financial fraudsters or confidence men (conmen for short), exhibit shared character traits and psychological insights, which have been described as 'grift sense' (Gibbon and Garrity 1962). 
Moreover, it is these shared character traits and psychological insights that constitute the essential reference points of financial frauds, as they enable conmen to 'exploit interrelational weaknesses' for criminal purposes. It follows that financial frauds, which have been committed at every stage of the history of capitalism (Mackay 1852/1995; Nash 1976), need to be understood and analysed in the context of these essential reference points.

The article will present two illustrative cases (Stake 1995; Yin 2003, 2004) that explicitly demonstrate the recurring reference points that conmen use to facilitate their financial frauds. The cases selected are constructed from the Ponzi and Madoff financial frauds. These swindlers who remain the two most well-known financial criminals of the $20^{\text {th }}$; and (so far) $21^{\text {st }}$ centuries, and given their notoriety are usually mentioned in relation to each other. The article will illustrate that their 'modus operandi' shared common reference points, as it owed as much to their sophisticated socio-economic insights and consequent exploitation of social capital processes, as it did to their sophisticated insights into criminal financial schemes and financial engineering. Furthermore, by analysing these financial frauds the article will examine how the embedded social fabric in networks generated economic outcomes, in these instances negative outcomes, as value was destroyed not created.

These illustrative cases will be analysed within social capital, which according to Adler and Kwon has matured from a concept to a field of research (2014). Social capital's rise to prominence can in part be attributed to it being a federated or 'umbrella construct', which facilitates trans-disciplinary research to examine complicated and integrated social phenomena from a multitude of perspectives (Hirsch and Levin 1999). (4) It is therefore unsurprising that social capital research lacks consensus and tends to be interpreted from the authors individual area of expertise (Foley and Edwards, 1999; Adler and Kwon, 2000). For 
this article, the understanding of the concept has been taken from Putnam's neoTocquevelllian and communitarian interpretation that ' ... social capital refers to connections between individuals-social networks and the norms of reciprocity and trustworthiness that arise from them' (2000: 19). This definition was selected as most appropriate as it emphasises networks, trust and reciprocity, which are all essential for understanding financial fraud. It is also an appropriate definition as its background assumptions were derived from historical research (Putnam, 1973). (5)

This article will demonstrate that social relations and the resources that inhere in these relations, as described by the social capital concept, can be negative and result in dis-utilities (Pillai et al. 2017). This contribution will add to an emerging field of analysis that considers abnormal or deviant organizational behaviour, in terms of opposing positive and negative forces, usually expressed in the light and darkness metaphor (Linstead et al. 2014). For example, in historiography this metaphor is associated with Petrarch's 'Dark Ages', to denote the decline of classical civilisation into medievalism. For this article the negatives of social capital will be described as its shadow aspect, which for financial fraud includes irrational decision making based on excessive in-group trust, as well as general credulity replacing due diligence. Thus, the article's theoretical contribution will be to develop understanding of historical phenomenon, in this instance of financial fraud, with the application of the shadow side of the social capital concept.

The article will proceed with a discussion of theories from criminology that explicate whitecollar crime. The article will then present illustrative cases of Ponzi and Madoff's financial frauds. The article will proceed with a discussion of social capital's ontological assumptions, optimistic bias, and the consequent strategy selected to operationalise the concept. Ponzi and 
Madoff's frauds will then be subject to a conceptual analysis to demonstrate that both of these white-collar criminals were experts at exploiting social capital for criminal purposes, with reference to the structural and relational sub-dimensions of social capital (Nahapiet and Ghoshal 1998, 242-266; Nielsen, 2003). A case comparison will then be presented. The article will conclude by arguing that the cases demonstrate how conmen use the shadow aspect of social capital for criminal purposes.

\section{Criminology and White-Collar Crime}

Criminologists have sought to theorise individual motivations and situational phenomena to explain the persistence white-collar crimes. The discipline of criminology was established by Sutherland who first coined the term 'white-collar crime' in 1939, and was then developed by his protégé, Cressey, who created the influential 'fraud triangle' model, as well as the orthodoxy that characterises fraudsters as 'trust violators' (1979). Criminologists have built on these foundations to develop a number of theories to explain white-collar crime (Payne 2012: 435-462). For example, Ponzi in the euphoria of the boom-time twenties, and Madoff in the neo-liberalism ascendancy of the nineties and noughties, can be understood with reference to 'Institutional Anomie Theory’ (Messner and Rosenfeld, 1994/2013). 1994/2013). This theory makes a macro-level analysis, which contends that contemporary societal norms over-promoted values associated with financial success and materialism, while under-promoting ethical values and the legality, and the legitimacy of this analysis is illustrated by the ubiquity of fraud in the Madoff era (Economist, 2012, 28 $8^{\text {th }}$ January). (6)

Neutralizing theory, which explains how white-collar criminals rationalize their behaviour by blaming the victims is also relevant, as both Ponzi and Madoff were convinced that their investors were complicit in the operation of the frauds: both swindlers stated their investors 
know the returns were too good be true and preferred to look the other way rather than be confronted with the unpalatable truth of the illegality of their investments (Sykes and Matza, 1957).

Social network analysis (SNA) is another perspective favoured by criminologists, who have studied the exploitative and deleterious effects of socially embedded networks and transactions. (7) These structural analyses of criminal networks draw attention to the importance of constructing and maintaining socially embedded networks to provide socially embedded proximity between criminal and victim, termed affinity frauds. (8) Social networks are therefore vital for facilitating fraud as they create proximity. In the syntax of conmen (confidence men), social networks allowed 'ropers' to identify the investors, the 'marks' to be 'roped in, told the tale and then fleeced' (Lewis 2012, 14). Nash et al (2013) have comprehensively reviewed the social network characteristics of 'Bernard Lionel Madoff Financial Securities' (BLMIS) considering the morphology (shape and structure) of the financial fraud's ego-centric and socio-centric networks.

There is however, a limitation of these structural approaches, in that they under-report the human and qualitative qualities of personal interaction and social groups. This limitation has been commented on by the leading social capital theorist Robert Putnam who has cautioned that: 'Knowledge needs a social context to be meaningful' (2000: 170-180). Accordingly, the extant social network (sometimes called structural) analyses of the BLMIS' financial fraud need to be expanded to take account of the social context of the fraudster's networks. This article will therefore expand the social network/structural perspective to analyse the qualitative social context of the fraud's embedded network interaction; that is to focus on the 
network interactions that are dependent on the 'persistence of human contact' as described by social capital (Cohen and Prusak 2005: 179-180).

It is also worth noting that while criminal profiling is an inexact discipline (Walters and Geyer, 2004), nonetheless there is consensus in criminology that white-collar criminals do not exhibit a homogenous profile or set of character traits (ibid, 280). Thus, according to orthodox criminology, there is no white-collar criminal archetype. Conversely, this article will contend that white-collar criminals exhibit a number of shared reference points, a contention supported by a reading of historical examples of various instances of white-collar crime. To take one example, John Law infamous for his 'Mississippi Scheme', exhibited conman essential reference points in being an intelligent, meticulous, charismatic and immaculately dressed crowd pleaser (super-networker), as well as being an inveterate gambler. Law, who possessed more than a tinge of narcissism, was also adept at the study of numbers. (Mackay 1852/1995, 1-38). Most importantly he had the ability to inspire trust in his investors to the extent that they failed to apply rational decision making or conduct due diligence. More recent examples of financial white-collar criminals such as and Ivar Kruger whose crimes were exposed after his suicide in 1932 (9); and the financier and insider trader Richard Whitney (10), described as Wall Street's 1930s version of Madoff, also exhibited these reference points of being able to exploit the resources that inhere in networks.

\section{Case Sources}

The article employs a qualitative approach (Denzin \& Lincoln, 2011; Silverman, 2011), using the qualitative case method (Stake, 1995; and Yin, 2004, 2010 and 2011). Further, these illustrative cases were also selected following Chell's recommendation, ‘...for analytical purposes to produce insight into the phenomena in question' $(2008,2012)$. 
Fraud is usually classified as a subdivision of criminology, termed white-collar crime or corporate crimes of the powerful (Newburn, 2007), and is also difficult to examine because of litigious and reporting constraints, as well as posing challenges associated with any criminal research area (Payne 2012: 4-19). Given these constraints the Ponzi case was constructed using various academic and journalist sources, including his autobiography, 'The Rise of $\mathrm{Mr}$ Ponzi' (https://pnzi.com). This autobiography is an unreliable a narrative of events, nevertheless it gives an acute insight into Ponzi's thoughts on how to construct and exploit social relationships. Narrative accounts of Ponzi's criminal career were referenced (Zuckoff 2005; Hurt 2009; Nars, 2009), as well as a number of papers that analyse Ponzi from a social network perspective (Baker and Faulkner 2004).

The Madoff case study relied on a number of sources including descriptive accounts of the financial fraud (Arvedlund, 2009; Markopolos 2010; Lewis 2012; Henriques 2017). This developing literature stream, also includes a sub-genre written from a social network (Nash et al. 2013). In addition, archival sources were also referenced from the court records of Madoff v NY, to include victim impact statements, and the defendant's Plea Allocution (www.justice.gov/.../united-states-v-bernard-1-madoff-and-related-cases).

\section{Carlo Ponzi: The Boston Swindler}

Ponzi arrived in America from Italy in 1903, later claiming in his autobiography that he had gambled away most of his inheritance on the voyage. He then proceeded to drift through a number of odd jobs including being a grocery clerk, road drummer (in modern parlance a sales rep), factory hand and dishwasher, before landing a position at the 'Banco Zarossi' in Montreal. Within a year the bank failed and Ponzi was convicted of forging bad cheques. 
After serving 3 years in jail, he was subsequently convicted of smuggling aliens into the US for which he received a further 2 years in federal prison. On release, Ponzi after a number of colourful adventures (https://pnzi.com, chapter 52; Zuckoff 2006, 52-54), he became a clerk and stenographer for the J. R. Poole Company in Boston. This company focussed on foreign assets, and Ponzi was quickly promoted to a supervisory role at \$50 per week. Dissatisfied with life as an employee he quit and set himself up as a commodities broker, narrowly escaping conviction for stealing cheese when hunger threatened (Zuckoff 2006, 86).

It was at this low ebb in August 1919 that Ponzi set in motion his most famous con. (11) The scheme was to exploit an alleged anomaly in international postal law that according to Ponzi permitted a guaranteed profit. Ponzi's scheme was to buy a type of foreign stamps named 'International Reply Coupons', which could be purchased overseas for a penny or two and redeemed in the United States for six cents. In theory, you could buy enough of the stamps to make huge profits: 'to get rich quick'. This was the basis for the fraud with Ponzi claiming his scheme meant that investors who bought into his fund would receive a $50 \%$ return on their money in 45 days; and a 100\% return in 90 days. Since banks at the time were paying five per cent interest annually, Ponzi's sales pitch aroused irrational enthusiasm, becoming an instant success with most investors piling in for the longer-term intent on higher returns, though Ponzi always stressed that they were entitled to withdraw money after 45 days. The scheme soon gained Ponzi a huge amount of cash and by the summer of 1920 deposits reached $\$ 250,000$ a day. Inevitably, this spectacular success aroused the interest of the local press, curious over whether this 'wizard of finance' could be legitimate. Ponzi's most perceptive critic was 'The Boston Post's' legendary financial journalist, Clarence Walker Baron, who immediately saw through the financial fraud and mounted a successful campaign 
to expose Ponzi, whose fall was as rapid as his rise. An insight into Ponzi's view of the financial fraud can be observed when on handing himself in to police Ponzi was asked by reporters whether he wanted to make a statement. 'The public deserves it, don't you think?' one reporter asked.

'The public deserves exactly what it gets, ' Ponzi said. 'No more, no less.'

Following a trial in 1920 Ponzi once again found himself behind bars, sentenced to 5 years in jail, with both his reputation and fortune in tatters. Ponzi was released in 1924 and launched another criminal scheme, focussed on land fraud in Jacksonville Florida, which led to further imprisonment and then deportation back to Italy. For the rest of his life he unsuccessfully pursued various frauds, including a flirtation with Italian fascism, and died unlamented in a charity ward of a Brazilian hospital in 1949.

\section{Bernie Madoff: The Crime of the Century}

'He would never be the most charming person in the room. He would make you feel like you were the most charming person in the room. That was his gift' (https://www.npr.org/2011/04/26/135706926/examining-bernie-madoff-the-wizard-oflies).

Zara Madoff ran a small brokerage firm that was investigated by the Securities Exchange Commission (SEC) for failing to submit financial documents in 1963 (Nars 2009, 194). Her son Bernie followed in the family trade, founding BLMIS in 1960. Initially he concentrated on making markets for small parcels of bonds, however his ambition was to enter the more lucrative market of trading equities. At first BLMIS struggled to attract clients and Madoff focused_his energy on exploiting familial and friendship and religious/ethnic ties as his: ' $\ldots$ early financial clients were friends and relatives in the New York Jewish Community' 
(Arvedlund 2009, 25). Madoff was therefore following a typical start-up strategy of relying on social contacts to build commercially valuable networks (Davidsson and Honig 2002; Jenssen and Greve 2002). Madoff who was an expert at inspiring trust, charmed his way via family ties into the good auspices of retired attorneys, teachers and other professionals, to the extent that they started to invest with his supposedly 'conservative' and apparently reputable investment fund. Thus, Madoff used his social ties to develop crucial intangible assets (Cooke and Clifton 2002).

His fortunes improved dramatically when Sol Alpern, a wealthy accountant, began spreading the word on Madoff's uncanny ability to provide excellent returns. Alpern neglected however, to mention to his wealthy friends that his enthusiasm was related to having lent his son-in-law $\$ 50,000$ to launch the broker-dealer business (Arvedlund 2009, 25-28).

In the 1960s, Madoff concentrated on making markets for small parcels of bonds, expanding the firm so that he could eventually enter the more lucrative market of trading equities. His firm prospered and in the early 1970s he was credited with being one of the financial sector's IT innovators, which aroused a hostile reception from the established brokers who hated computerization, and according to Madoff: '...even had congressional hearings against me' (Gelles and Tait FT, 2011). Despite this opposition BLMIS continued to prosper and established itself as one of the largest independent trading operations in the securities industry, to the point that it had $\$ 300$ million in assets in 2000 at the height of the Internet bubble and was ranked among the top trading and securities firms in the world.

Driving this growth was Madoff assiduous cultivation of his reputation, both as an innovator and as 'America's Financial Guru'. Madoff possessed undoubted entrepreneurial flair and took the credit for the exploitation of computer technology to automate stock trading. It is also worth noting that the speed of technological change, which Madoff very much a 
pioneered, posed challenges to the financial authorities, who found decentralized trading difficult to regulate (Arvedlund 2009, 40-44).

In promoting technology trading Madoff also established himself as a vocal lobbyist for deregulation: he donated heavily to both the Democratic and Republican campaigns and sat on a number of committees advising on stock market restructuring, as well as acting as the chairman of NASDAQ. It is also significant that Madoff operated a hedge fund, and these funds were not required to register with the SEC until 2006, and hence were not subject to any regulatory scrutiny (Arvedlund 2009, 151). Madoff therefore exploited technology innovations, as well as regulatory lacunae to promote his firm and his criminal activity.

Madoff claimed the fraud began in the 1990s, another view held by investigators was that the criminality started earlier in the 1980 s, yet another and perhaps more plausible judgment is that BLMIS from its inception was a fraudulent organization (Nars 2009, 228-233). Madoff's fraud which was only exposed by the liquidity squeeze, can be explained with reference to his reputation for returning investments promptly. Another reason was that he charged very low commissions, when the industry standard was for expensive financial fund fees. Madoff also distributed lavish fees and commissions to feeder funds, and further his generous donations to charities created reputational capital to the point that it was hard to consider that this noted philanthropist could be anything but legitimate

Industry insiders had long puzzled over the success of Madoff and not everyone was shocked when the truth emerged that he had been running the biggest 'Ponzi' scheme in history. Harry Markopolos, a certified fraud examiner, was asked in 1999 by his employers, 'Rampart Financial Management' to reverse engineer Madoff's strategy to find out how BLMIS was winning their potential client's business. Markopolos claimed that: 'When I saw the return stream, I knew it was a fraud in five minutes.' He also claimed it took him only 20 minutes to 
prove it was a fraud. (Arvedlund 2009, 90). Nevertheless, Madoff continued to prosper, despite Markopolos' best efforts to stop him, including reporting his suspicions to the financial authorities (Ibid, 196-200).

Madoff was convinced that he would be discovered on two occasions in 2003-4 and again in 2006. The SEC however, failed to check the basics, such as investigating his account with Wall Street's clearing Houses, and into dealing firms that were supposedly handling his trades. It is also notable that BLMIS was mistrusted by industry insiders. Goldman Sachs refused to put the fund on its approved list of intermediaries as Madoff's strategies would have required massive trading in stock options and derivatives, and inexplicably none of their professionals had seen or heard of these trades: Credit Siuisse also recommended its clients to withdraw their Madoff investments as it could not fathom how BLMIS made its returns (Nars 2009, 212).

Evidence subsequent to the financial fraud's collapse confirmed that Madoff had made few, if any stock or options trades for clients over the years. Instead his operation consisted of taking money in from new clients and paying it out to existing clients. Therefore, Madoff was running a giant pyramid scheme, which collapsed when depositors started withdrawing their money faster than deposits could cover. In the end the scheme caved in because large investors wanted to take their money out, not because they had lost faith in Madoff, but rather because they needed cash to cover other bad investments exposed in the financial downturn. Madoff always claimed that his firm was so successful due to an obscure 'index option', 'split-strike' conversion strategy, an explanation that was also convincing enough to gull SEC investigators. Madoff further insisted that the split strike financial strategy was a proprietary secret and hence his investors had to sign confidentiality agreements. (12) 


\section{Social Capital: Redressing the Optimistic Bias}

Pierre Bourdieu, James Coleman and Robert Putnam, are usually taken as the key founding scholars in social capital (Baron et al, 2000: 2-3; Field 2003: 13) and one of the few areas of accord between them was to interpret social capital as conferring advantages, thus it was taken to be an asset (Bourdieu 1985, 243; Coleman, 1990, 303; Putnam 2000, 319-325). This optimism remains evident in reviews of conceptual literature, (Lee, 2009; Portes and Vickstrom 2011), confirming Dasgupta's observation that: 'The recent literature on social capital has a warm glow about it' (2005: 28).

There is however, an emerging literature on the dark-side, or shadow aspects of social capital. Portes is arguably the leading scholar in this literature stream (1998, 2014; Portes and Lansdolt 1996; Portes and Vickstrom 2011), and he has summarised the negatives as fourfold: ' ...exclusion of outsiders, excess claims on group members, restrictions on individual freedoms and downward levelling of norms' (1998: 15). Uzzi's research into the negative effects of being over-embedded in the New York garment industry is analogous in emphasising the disadvantages of excessive network density (1996).

The limited negative social capital literature has also coalesced into the deleterious effect of closed networks. Putnam, has cautioned about the negative effects of closure (2000, 350363), in his terminology of 'bonding capital', '... which bolsters are narrow selves' (2000, 23). The same phenomenon has been noted by Fukuyama (2001) and Dasgupta has reached the same conclusion on the dark-side of social capital, as he draws attention to network exclusivity, inequalities and exploitation (2005: 25-28). The negative effects arising from bonding social capital and its dense networks and closure mechanisms were recently 
reviewed by Pillai et al, who identified '... the non-rational escalation of commitment' (2017).

There is also limited social capital literature in relation to corruption (Graeff 2007; Graeff and Sense 2013). These authors see social capital as a counter-weight to corruption, for instance contending that the '... augmentation of positive social capital could work as an effective counterforce to corruption'. In contrast, Uribe has argued that social capital networks provide fertile grounds for the development of trust that can expedite corruption (2013).

\section{Social Capital: Ontological Assumptions}

Social capital is more than the sum of its parts, and though it can be de-composed into its component dimensions for research purposes, nevertheless its essential qualities have to be considered in a synoptic or holistic purview. Thus: 'Claiming that social capital can be studied as a dependent or independent variable ignores the possibility of complex causal mechanisms, which are not the exception but the rule' (Adam and Roncevic 2003: 167). The extent social capital can be decomposed into sub-dimensions, while maintaining its integrity as a unifying concept has also been questioned by Maak (2007) and Anderson, et al (2007). Based on these observations this article conceptual understanding is that any sub-dimensions are complementary, inter-related and fluid (Jacobs 1961/1993, xvi-xvii; Liao and Welsch, $2005,347)$.

It also follows from this holistic ontological understanding that any conceptual decomposition should be parsimonious in its number of sub-divisions. In conceptual literature the most prevalent approach to operationalizing social capital is to adapt Nahapiet and Ghoshal's 3-dimensional decomposition (1998: 242-266). This article, however will modify 
this model to exclude the 'cognitive' dimension, to be in keeping with the ontological understanding, as the limited decomposition of social capital into two sub-dimension facilitates the synoptic view of the concept. Further, Nahapiet and Ghoshal's 'cognitive' dimension was specifically designed for their study into intellectual capital $(1998,244)$, and the data under this dimension could be captured under the relational dimension. Therefore, this research will limit its analysis to the following sub-dimensions:

- Structural Dimension: '...refers to the overall pattern of connections between actors that is who you reach and how you reach them' (1998: 244).

- Relational dimension: '...describes the kind of personal relationships people have developed with each other through a history of interaction...It is through these ongoing personal relationships that people fulfil such social motives as sociability, approval and prestige' (Ibid).

\section{Structural Dimension: Prior Start-Up Social and Family Networks}

In Hebrew Madoff could be described as a Shidduch, meaning a matchmaker; and in behavioural economics both Ponzi and Madoff could be termed as 'connectors' (Gladwell 2001, 30-59). In network syntax, they cultivated 'weak' ties for 'brokerage benefits' and both intuitively grasped that: 'People and groups who do well are somehow better connected' (Burt 2005, 5).

Ponzi and Madoff both relied on prior social and family connections at the start up stage of their frauds, which is an orthodox entrepreneurial approach to launching new ventures (Blundell and Smith 2001, 490). For illustration, Ponzi registered his uncle J.S. Dondero as his partner for his 'Securities Exchange Company': Ponzi had considerable debts and the inclusion of his in uncle, who remained oblivious that he was a partner, added to the financial 
creditability of his company (Zuckoff 2006, 118). Madoff also followed this pattern of exploiting familial and friendship ties (Arvedlund 2009, 25). Madoff first investors were lured into the fraud in social and non-commercial settings, for instance in the Catskills were New York Jews 'vacationed'. In this relaxed social setting Madoff, who was an expert at inspiring trust, charmed his way via family ties. Madoff therefore acted in accordance with research that the extensive personal ties used by entrepreneurs often lead a blurring of business and social life, with mixed consequences (Jenssen and Greve 2002, 254-55).

For the frauds both Ponzi and Madoff purposefully developed weak ties to serve as recruitment networks. Madoff was perceptive enough to realize that: 'Who better to refer new clients than current satisfied clients' (Arvelund 2009, 27). The fact that these agents usually took a fat commission was kept secret from the investors, and as they brought clients into Madoff's fund, the agents also grew inordinately wealthy. For illustration of the recruitment network, Robert Jaffe, a noted philanthropist like Madoff, 'worked' the 'Palm Beach Country Club' to the extent that over $30 \%$ of its members eventually invested with Madoff. However, Jaffe failed to tell his 'golf buddies' about the commission he charged, or even the fact that they were investing their funds with Madoff. In return for this deception Jaffe became extremely wealthy, and the fraud continued apace. This deception also meant that a considerable number of investors in Madoff had no idea that they were connected to the fraud until they received news that the Ponzi scheme had collapsed and that they had lost their investments. The degree of criminal complicity of Madoff's agents is open to question (some perhaps were innocents), though Madoff was in no doubt over their criminal culpability as he claimed that four of his earliest investors - Jeffry Picower, Stanley Chais, Norman Levy and Carl Shapiro - had helped recruit customers for his firm in the late 1980s, when Madoff was 
having difficulty unwinding positions in the markets. 'They were complicit, all of them. Which is why they being all settling' ( $8^{\text {th }}$ April, 2011, Financial Times).

Ponzi's fraud had also hit upon a similar feeder network strategy, and in theoretical terms Ponzi and Madoff were acting in line with literature emphasising the returns of weak ties (Granovetter 1973). This accords with Burt's conclusion that: 'Companies with a heterogeneous mix of alliance partners tended to enjoy faster revenue growth, and a dramatic advantage in obtaining patents' $(2005,76)$. The development of these weak tie recruiter networks also supports a process theoretical understanding that is self-generating, dynamic and subject to uncertain trajectories. As Burt's research into financial employees illustrates: '... social capital can be said to accrue to those bankers who already have it' (Burt, 2006, 77). Ponzi and Madoff's successful recruiter networks are therefore vivid illustrations of social capital's weak tie theory in that they were extensive and self-generating and once established they developed in unpredictable trajectories. (Granovetter, 1973)

As well as cultivating weak tie networks Ponzi and Madoff were astute enough to enhance their schemes by constructing closed networks, which is analogous to the criminology theory of exclusivity fraud. This dual approach to networks was not contradictory, and theoretical literature is clear in the respective benefits that accrue from different network tie strengths. For example, according to Burt: 'Brokerage is about coordinating people between whom it would be valuable, but risky to trust. Closure is about making it safe to trust' (Burt, 2005, 97). Furthermore, according to Jenssen and Greve dense, an embedded network may provide better information and avoid information overload $(2002,263)$, an observation supported by Westerlund and Svahn (2007). Putnam has also noted the benefits of strong embedded ties: 
'The denser such networks in a community, the more likely that its citizens will be able to cooperate for mutual benefit' $(1973,173)$.

In terms of closed networks both Ponzi and Madoff preyed on their own ethnic/cultural networks which both shared an unhappy history of being marginalised. Ponzi for example, considered that Italians and Jews were lumped together as 'untouchables' by the Bostonian financial establishment (Zuckoff, 2005, 173). He was also swift to defend the supposed targeting of the Italian community in an article in the Boston News Bureau by the esteemed financial journalist Clarence Brown, who levelled the charge that Ponzi was exploiting his own Italian immigrant community. Ponzi responded in a man-of- the-people-pose, filing a $\$ 5$ million lawsuit. Ponzi also promised that if he won the suit that he would donate the $\$ 5$ million to charity (Zuckoff, 2005, 219-220).

Coleman also observed that social capital is more likely to be created as an oppositional response $(1990,319)$, which is germane to this discussion as both the Italian and Jewish community's in Ponzi and Madoff's frauds regarded themselves as marginalised and discriminated against, in comparison to what they perceived as the WASP establishment. It followed that there was an oppositional response to perceived injustices to forge a strong sense of community with strong bonding social capital. (ibid, 20). However, the reverse side of this high trust context was that a skilful financial criminal could exploit this community resource, in part by emphasizing their shared cultural and ethnic ties. Ruth Madoff, for illustration co-authored, 'The Great Chefs of America Cook Kosher' (1996), and both swindlers donated ostentatiously to respectively Italian and Jewish charities. (13) 
In addition to their ethnic networks, Ponzi and Madoff focused on cultivated close ties with key stakeholder groups. For obvious reason both cultivated networks comprising individuals from the regulatory, legal and police authorities, Madoff, a more astute swindler than Ponzi also fostered close ties with the financial regulators. For example, Madoff as well as serving as chairman of the NASDAQ, also acted as an advisor to the SEC on market structure and other issues. His influence over the SEC was such that Markopolos well-founded warnings were ignored: '...it seemed that Madoff had cast a shadow over the SEC' (Arvedlund, 2009, 196).

In summary, the closed network literature emphasises that, '...not all connections connect us to resources that matter' (Briggs, 2004, 152), and Ponzi and Madoff were calculating enough to target the most significant networks for facilitating their respective fraud. For example, Madoff developed close ties with the SEC by training their newly appointed lawyers in the hard to codify, context specific insider knowledge of Wall Street (Arvedlund, 2009, 195), resulting in closed tie relationships, which served to screen him from the concentrated gaze of investigators. Ponzi's more fleeting swindle also prospered in part because knew the value of cultivating a closed network with the police and prominent journalists.

\section{Relational Dimension}

Ponzi and Madoff both purposefully targeted their own ethnic groups for the victims in their frauds (Perri and Brody, 2011, 34). Ethnicity is a concept defined with reference to language, religion, ancestry and location characteristics, and Ponzi and Madoff both surrounded themselves with members of their own Italian and Jewish communities. Thus, creating close proximity with those of a similar background who shared a sense of identification, which can be understood as '...the process whereby individuals see themselves as one with another 
person or group of people' (Nahapiet \& Ghoshal 1998, 256). This is a typical response from ethnic minority entrepreneurs who will trade within a network based on common values and experiences relying on the trust of a shared social network (Portes and Sensenbaum, 1993). In social capital literature the same observation is made in Putnam's bonding capital $(2000,362-$ 363); and in Lin's conclusion there is a preference for homophilious interactions in networks (2001, 46-54). These observations are also detailed in, 'Reference Groups as Perspectives' (Shibutani, 1955) a concept that notes that economic activity is often based on shared sociocultural and religious values and characteristics. (14)

Ponzi and Madoff understood the importance of being embedded in these ethnic communities: it wasn't enough to be identified as either Italian or Jewish, they both realized they had to be known as leading and integral members of their respective communities. This is a socio-economic insight, embeddedness being first coined by Polanyi (1944/2001). For illustration Ponzi promoted himself as 'a man of the people' who told a rags-to-riches story of the Italian immigrant (like most of his investors) who had amassed a fortune in the teeth of opposition from the establishment. His popularity was such that crowds cheered him as the Boston financial establishment levelled accusations over his credibility. Expertly he promoted his popularity by asserting that the establishment wanted to keep the secrets of big profits from the masses, meaning Italian immigrants. He was hailed as a hero and walking between the Hanover Trust banks a quickly assembled crowd shouted: 'Ponzi for mayor' and 'Ponzi for governor' (Zuckoff, 2006, 221). Ponzi adroitly maintained a high level of popularity in his own community, by posing as one of them with their best interests at heart. In sum, Ponzi's seductive pitch was that he had found a way of providing financial opportunities for the masses, which previously had been the exclusive privilege of the established wealthy elite. 
Madoff also acted in accordance with these insights, and for illustration donated heavily to ethnic (Jewish) charities, became a member of the Board of trustees for Yeshiva University and proclaimed his devotion to the Jewish religion and culture. Madoff was perceptive enough to recognize that charity, and more generally philanthropic activities in his own community were an excellent opportunity to develop feeder networks. This approach fitted in with Madoff's preferred sales pitch of avoiding financial or 'capital introduction' parties, which would be full of financially savvy investors, who could ask many awkward questions. Instead, he preferred to target fellow philanthropists by word of mouth recommendations, and there was a concerted effort by Madoff and other members of his family to court the charity circuit, sitting on the boards of many charities and donating money to many others. This networking gave Madoff two opportunities. First, it allowed him access to high society that added lustre to his brand: it made him more respectable and consequently credible. Second, it allowed him to aggressively market his products to gullible charity commissioners and hence provided a lucrative source of investors. The success of the Madoff's in convincing charities to invest an be gauged by the reforms being planned to charitable foundations altering their size and structure in order to decrease their reliance of 'personal ties' (Jagpal and Craig, 2009).

Ponzi and Madoff therefore grasped that their frauds depended on being accepted as upstanding members of their own communities, as their own communities provided the bulk of the investors. This perception accords with Fukuyama's appreciation of culture in economic life which concludes: 'As Adam Smith well understood, economic life is deeply embedded in social life, and it cannot be understood apart from customs, morals, and habits of the society in which it occurs. In short, it cannot be divorced from culture' (Fukuyama, 1996, 13). 
Ponzi and Madoff also relied on maintaining a reputation above reproach as a key relational asset. For this analysis Burt's two-level reputation generating hypotheses are most apt. The first 'bandwidth hypothesis' chimes with everyday assumptions in which the actor owns their reputation, in the sense that they define their behaviour, which in turn defines their reputation. Ponzi and Madoff were both high profile and seemingly success self-made men to promote their reputation via this obvious route, working assiduously to maintain a reputation for credibility. For instance, Madoff cultivated a brand identity that was conservative and reassuring: always immaculately presented, a committed family man and vigorous philanthropist who didn’t live an ostentatious lifestyle (Arvedlund 2009, 53). The Madoff's were also noted for their conservative values, and paradoxically were associated with low risk financial strategies: Madoff to his cautious investors appeared anti-risk. Further his returns were good but remained within the realms of what a skilful and lucky trader could achieve in a good year 8-12\% per annum-except Madoff uniquely achieved these returns every year. Ponzi also stressed his conservative social and political values (red-baiting) and emphasised his deeply rooted 'American Standards' and generosity by donating to deserving charities. He also presented himself as utterly committed to his wife Rose, and to garner mass support, as someone who was thinking about supporting a 'wet' candidate, opposed to Prohibition (Zuckoff 2006, 219-222).

Ponzi and Madoff also exploited the processes described in Burt second 'echo hypothesis'. In this hypothesis reputation is not owned by the individual, but rather is owned by: '...the people in whose conversations it is built, and the goal of those conversations is not accuracy so much as bonding between the speakers' $(2005,196)$. In consequence: 'Reputations do not emerge from good work directly so much as from colleagues' stories about the work...the source of the reputation is stories third parties are telling one another' (Ibid, 219-220). Ponzi 
and Madoff both appeared to grasp that positive gossip was essential to maintaining their reputational assets, as from this perspective reputation is dependent on an individual's freedom to make judgements: thus, reputation is transcendently motivated (Pastoria et al. 2008, 335). For example, Ponzi was a hero to the poor Italian immigrants in Boston because he made sure they knew that he had made-good from a shared impoverished background (Zuckoff 2006, 221). It is striking even as Ponzi fraud unravelled his popularity on the streets remained undiminished: always with an entourage numbered in the hundreds he continued to be hailed as a hero by the assembled crowds, right until he confessed and admitted the fraud. Equally, Madoff was admired and much talked about as the former chairman of the Nasdaq stock market, a friend of regulators, and vice-chairman of the National Association of Securities Dealers, his industry's self-regulatory body. He was also a role model in that he lived a gilded but at the same time low-key life-style, flitting with his family between a penthouse in New York and holiday homes in Palm Beach and Long Island, travelling in private jets and on his yacht, called 'Bull'. Madoff also understood the value of acts of kindness for spreading positive word of mouth, and consequently constructed a caring persona (15). One reason Judge Chin cited for imposing such a long sentence was that he was deeply moved by the victim impact statements and letters including one from a widow that recounted how Madoff had visited shortly after her husband's death. According to her letter, Madoff had consoled her with a hug and with the reassuring words: 'Don't worry your money is safe with me'. Later she deposited her pension fund with BLMIS and subsequently lost all of her investments with dire personal consequences (Lewis 2012, 26-31).

Madoff and Ponzi further enhanced their reputations by cultivating highly respected network ties that could serve as a conduit to channel further victims into the fraud. In social capital literature Lin has noted that reputation is promoted by;' ...recruiting actors with a reputation 
established elsewhere in society' $(1999,154)$ and Ponzi and Madoff fully understood the value of these network ties for facilitating their fraud. For example, Madoff developed a close commercial relationship with Michael Engler who ran a brokerage firm and enjoyed high status in his suburban community, based on his exemplary war record. Engler recommended many veterans to invest with Madoff, and these military ties also served to ensnare an extensive network of unsuspecting investors, who were in turn connected to these veterans. Ponzi also made great play of his bank directorship of the hitherto sober and respected Hanover Trust Company, to enhance his credibility and reputation.

Ponzi and Madoff both targeted high trust religious/ethnic settings and social structures. For illustration, Madoff was skilled at targeting investors when they were at their most vulnerable, as noted by Judge Chin who admitted to being swayed in the severity of his sentence by a victim statement of a widow (Arvedlund, 275). Madoff's technique was to interact or approach investors in non-financial settings, thus to ingratiate himself in social and religious milieu's as he knew that these environments fostered an ambience of trust in which investors would be more likely to see Madoff as 'one of us', and in consequence let their financial guard down. These trusting environments included country clubs in Palm Beach and the Hamptons and synagogues in Florida, New York, Minnesota and Los Angeles (Ibid, 26). Ponzi also detailed in his autobiography how he exploited the trust of a naïve priest (https://pnzi.com, chapter 7).

Ponzi and Madoff were also expert at gaining trust without giving up a lot of information. This is significant as high levels of trust and a culture of shared values facilitate white-collar crime. Conversely, in low-trust cultures transactions are scrutinised in detail and economic actors are wary of being cheated. Therefore, though high trust culture can create economic advantages, for instance in terms of reduced transaction costs (Fukuyama, 1995), at the same 
time high level of trust create opportunities for fraud. Trust can be understood as a relational aspect of social capital that was essential to both criminals, as investors relied on this relational intangible instead of carrying out due diligence. In social capital literature, it has been contended that levels of trust are related to levels of social capital (Fukuyama 1995; Putnam 2000). Fukuyama has stressed the importance of trust and 'ingrained ethical habit' (1995) for 'lubricating' market-based transactions.

Further, Madoff followed a typical fraud method, in claiming to have privileged 'insider knowledge' based on his special connections. Thus, it was taken that Madoff possessed exclusive bridging capital, or network brokerage opportunities that offered the privileged few access to highly lucrative financialopportunities. Furthermore, according to Cohen and Prusak trust is best thought of situational $(2001,179-180)$ and Madoff created the illusion of a very advantageous situation for his investors. High level of trust can be observed in the loyalty of Madoff's investors, with widows recounting how their deceased husbands' final words had been to implore them, 'to never sell their Madoff holdings' (Arvedlund, 2009, 50). Ponzi was also an excellent salesman who claimed that he was a 'wizard of finance', as well as being a self-proclaimed man of the people. Ponzi was trusted enough to attract investors, even though the precise nature of how his postal scheme returned any profits was never transparent. It is also significant that Granovetter has noted from a social network perspective that victim/offender relationships in financial scams are based on a surprising level of intimacy (1992, 43-44). In Madoff's case it has been claimed that this intimacy extended to a shared set of beliefs (Perri and Brody, 2011).

\section{Case Comparison}

There are striking similarities between Ponzi and Madoff in that they perpetuated schemes '... of a size and scope that was unheard of at the time' (Hurt 2009, 977). Consequently, 
Ponzi was described in the Boston Post as the king of all the 'get-rich-quick magnates' (Zuckoff 2006, 285), and Madoff has been dubbed the 'Criminal of the Century' (Nars 2009, 194). Further, whether by design or vicissitudes of fortune Ponzi and Madoff came to personify the dark-side or shadow aspect of their respective times; that is, they came to personifying different epochs of unethical financial hubris, as described by the anomie theory in criminology (Messner and Rosenfeld, 1994/2013).

The frauds also shared a number of operating characteristics, which have been discussed in detail under the social capital structural and relational dimension analysis. For example, both frauds started out as affinity frauds, with Ponzi targeting Boston's Italian community and Madoff focus being on the Jewish community (Ventura and Daniel 2010; Perri and Brody 2011). Furthermore, both frauds played on the idea of championing excluded groups, confirming the view that social capital is readily created in opposition (see relational dimension). Ponzi stressed the outside nature of the Italian community against the establishment WASP bankers (see structural dimension), and Madoff played on the Jewish community being over-sensitive to accusations of avarice and hence reluctant to conduct diligence (Lewis 2012, 201-203).

Both fraudster also understood the strategic importance of maintaining good relations with regulatory authorities, (Zuckoff, 2006, 119; Arvedlund 2009, 201). Madoff grip over the SEC was such that he would claim that every time a commission investigator came to his office they would ask for a job application (Lewis 2012, 73). Another point of reference between the conmen was that they both faced formidable adversaries, who worked tirelessly to expose their frauds. Ponzi was brought down by Clarence Baron the esteemed editor who saw it as his duty to expose the fraud for the good of his readers (Zuckoff 2006, 219-220), while Madoff was pursued by the financial analyst Markopolis who worked tirelessly to expose the 
criminality at BLMIS, as he later detailed in his book 'No One would Listen: A True Financial Thriller' (2010). One can speculate that these adversaries saw thorough the conmen's artifice and recognised their true venal core, as described in neutralizing theory (Sykes and Matza, 1957).

Conversely, it is worth noting that there are differences between the cases, which is consistent with the argument of this article as the contention is that financial frauds share essential reference points not that frauds will be identical. In these cases, one point to a number of differences. First, Ponzi's scheme was short-lived and concentrated on Boston, in contrast Madoff's fraud was long-term, and global in its corrosive reach. Ponzi's financial fraud was also generated and perpetrated by its eponymous founder. The agents and hired staff Ponzi employed, were probably duped to the extent of the criminality (Zuckoff 2006, 232), and following Ponzi's conviction there were never any demands for further prosecutions related to the fraud. It is indubitable though that Madoff had collaborators, a number of whom were pursued and convicted by the authorities (Lewis 2012, 56-57). The question remains unanswered as to the extent that Madoff was responsible for the totality of BLMIS criminal enterprise. Markopolis for one, is convinced that Madoff's operation on the $17^{\text {th }}$ floor of the Lipstick Building contained many collaborators beyond the immediate Madoff family. For example, Frank Di Pascali Madoff's chief finance officer admitted his guilt as part of a plea bargain (Lewis 2012, 224), and it is also notable that two long-time Madoff investors, Carl Shapiro and Jeffrey Piccower received a much higher return than other investors (Arvelund 2009, 235-241) It is under-discussed and telling that not all of Madoff's investors lost money, as the majority took out more than they invested (Nars 2009, 220).

Another significant difference is that in 1920 Ponzi was sentenced to a prison terms of 5 years and released early in 1924, whereas Madoff was given the maximum tariff of a 
symbolic 150 years (16). One explanation for the disparity in these prison terms is that since the Global Financial Crash (GFC) punishments for white-collar criminals have become more onerous, which it has been argued reflect the material values that dominate in contemporary society (Hurt 2009, 947-987).

\section{Conclusion: The Shadow Aspect of Social Capital}

The article has presented two cases of fraud to illustrate of how shadow social capital can be leveraged by sophisticated fraudsters to facilitate financial fraud. The cases demonstrate that there are shared essential points of reference or negative social capital characteristics between Ponzi and Madoff.

The article has detailed that Ponzi and Madoff were masters at exploiting the dis-utilities of social capital and their fraud were predicated on sophisticated socio-economic insights into social interaction, as well as acute insights into behaviours and characteristics. The social capital analysis complements criminology literature by examining financial crime's human factors and draws attention to the resources that inhered in the fraudsters social interactions and structures, in what remains the most heavily regulated industry in America. Further, the originality of this article has been to consider the recurring features of fraud from the shadow aspect of social, which expands criminology's SNA approach of investigating the exploitative and deleterious effects of social networks, while also acknowledging the persistent social (capital) realities of social interaction in white-collar crime. Accordingly, the article has examined not just the pattern or structure of social relations, but also the more qualitative embedded, relational social realities that are built up over time, through reiterated interactions to create the social fabric of criminal network structures. From this point of view the article 
has demonstrated that social capital analysis can move beyond its theoretical orthodoxy of being the 'celebration... [of an] an unqualified public good' (Portes and Levine 2014, 18407).

The implication of this article is that fraud will continue to be committed by white-collar criminals so long as they have the opportunity to exploit the resources that inhere in networks. Safeguards however, can be introduced to identify and prevent these criminal activities if the essential reference points are recognised and countered. For illustration, one consequence of Madoff's fraud was a demand for more stringent regulations relating to the financial management of charities to ensure due diligence, to prevent trustee's making decisions based on the 'special trust' favoured by financial criminals (Jagpal and Craig, 2009; Perri and Brody, 2011: 43-44).

\section{Notes}

1. St Peter's Church in Westminster was sold to fund repairs at St Paul's Cathedral in the City of London. Alternatively, the phrase may originate in paying for St Peter's in Rome and St Paul's in London during the Reformation.

2. See Sunderland, who first used the term 'White-Collar Crime' in a 1939 article. Also see Smith et al, (2011, 7-10) for a discussion of the debate between criminologist who define their area very precisely, as opposed to those who understand it as a broad inter-disciplinary subject focused on criminal behaviour: this article will take the latter, broad definition. This broad definition is detailed by Payne, (2012, 435-462), who argues that theoretical explanations from criminology for white-collar crime include: cultural theory; deterrence and rational choice theory, strain theory, learning theory; neutralizing and justifying white-collar crime; control theory; and self-control routing activities theory.

3. Ponzi and Madoff's frauds that have been termed bubble schemes, pyramid frauds, Ponzi frauds, affinity frauds, swindles, investment crime, and crimes of the financial system. For this article 'financial crime' will be used as a catchall term to describe Ponzi and Madoff's frauds. Financial crime has been defined by the 'Financial Conduct Authority' as '....any kind of criminal conduct relating to money or to financial services or markets' https://www.handbook.fca.org.uk/handbook/glossary/G416.html

4. Coleman describes social capital as '... aspects of social structure that enhance opportunities of actors within that structure' $(1990,302)$, while Putnam refers to generalized reciprocity quoting Tocqueville's: 'Self- interest rightly understood' (2000, 135). According to Lin social capital is: 'social relations with expected returns 
in the market-place' $(2001,19)$, and Flap's definition is, '....an entity consisting of all future benefits from connections with other persons' $(1988,136)$.

5. Putnam researched the causes and outcomes of different levels of civic engagement in Italian regions (1973), and his analysis was controversial (Manning, 2010). Bolin et al. (2002) have also argued in favour of citizenship having a generative role for social capital.

6. See, Lewis, (2012, 41-42) who, details cases exposed from 2008-2010 involving Tom Peters, Robert Allen Stanford and Scott Rothstein.

7. Criminal networks have been analysed by Cressey, who created the influential 'fraud triangle' model and well as the orthodoxy that characterizes fraudsters as 'trust violators' (1979).

8. Affinity fraud refers to financial scams that prey upon members of an identifiable groups, such as racial, religious and ethnic communities, the elderly, professional groups, or other types of identifiable groups. The fraudsters who promote affinity scams frequently are -or pretend to be-members of the group' (Perri and Brody, 2011, 34).

9. 'Fraud and Financial Innovation: The match King', The Economist, December 19th, 2007. 'Introduction to Kreuger Genius And Swindler' by Galbraith, available at: www.archive.org/.../kreugergeniusand $006788 \mathrm{mbp} / \mathrm{kreugergeniusand006}$

10. See, MacKay, 2013, who details that Whitney was declared bankrupt in 1938 and was found to be $\$ 6$ million in debt. He pleaded guilty and was sentenced to five to ten years and served three years in Sing Sing and on his release found work as the manager of a dairy farm outside Boston.

11. Zuckoff, states that it is highly likely that Ponzi fraud was inspired by an earlier swindler, 520\% Miller: 'Honest Bill's' promise on what investors would receive over one year.

12. Avedon $(2009,279)$, notes that the investors: ' ...even honoured Madoff's bizarre request: not to tell anyone he was managing their money.'

13. Madoff targeted charities for his fraud, but he would never accept any investments from his favourite charity: 'Lymphoma Research Foundation'. His son Andy suffered from lymphoma and the Madoff' were generous donators, over \$1 million in 2007. (Levenen 2008). "One Madoff charity goes Unscathed" Fortune, December 17th. Available at: 'archive.fortune.com'.

14. Shibutani $(1955,109)$ defines reference groups as a, '...a group which serves as the point of reference in making comparisons or contrasts, especially in forming judgments about one's self'.

15. Employees loved working for the Madoff's and most stayed with them till the bitter end. See, Arvedlund for how '...Bernie garnered the loyalty- and cooperation-of those around him (2009, 180-181).'

16. 150 years was the total maximum for the maximum for the 11 counts for which Madoff was convicted, and three times as long as recommended by the federal probation office.

\section{References}

Adler, P. S., and Kwon, S, W. 2002. "Social Capital: Prospects for a New Concept." The Academy of Management Review, 27 (1): 17-40.

Adler, P. S., and Kwon, S, W. 2014. "Social Capital: Maturation of a field of Research." Academy of Management Review 39 (4): 412-422. http://dx.doi.org/10.5465/amr.2014.0210 Arvedluund, E. 2009. Madoff, The Man who Stole \$65 Billion. London: Penguin. 
Baker, W. E., and Faulkner, R. R. 2004. "Social networks and the loss of capital." Social Networks 26: 91-111.

Baron, S., Field, J. \& Schuller, T. (Ed) 2000. Social Capital: Critical Perspectives. Oxford University Press. Oxford.

Bourdieu, P. 1985. "The forms of capital." In, Handbook of theory and research for the sociology of education, edited by J. G. Richardson. 241-258. Greenwood. New York. Burt, R. S. 2005. Brokerage and Closure. Oxford: Oxford University Press.

Carozza, D 2009. "Chasing Madoff : An Interview with Harry Markopolos." Fraud

Magazine. May/June.( http://www.fraud-magazine.com/article.aspx?id=313)

Carr, E. H., (1961) 1985. What is History? London, Penguin.

Cassel, P.G. and E. Erez. 2011. "Victim Impact Statements and Ancillary Harm: The American Perspective." Canadian Criminal Law Review, 15: 149-196.

Castiglione, J.W., Van Deth, and G., Wolleb. (Ed). 2008). The Handbook of Social Capital. Oxford University Press. Oxford.

Chell, E. 2008 (2nd Ed), The Entrepreneurial Personality, A Social Construction. Routledge. East Sussex.

Cohen, D. \& Prusak, L. 2001. In Good Company. How Social Capital Makes Organizations Work. Boston: Harvard Business School Press.

Coleman, J. S. 1990. Foundations of Social Theory. Harvard: Bellknap Press of Harvard University Press.

Cooke, P. and Clifton, N. 2002. "Social Capital and the knowledge Economy. Regional Industrial Research Report. 39." Centre for Advanced Studies. Cardiff University.

Dasgupta, A. 2005. "The Economics of Social Capital." Economic Record, Vol 81: 2-21.

Cressey, D. R. 1973. Other People's Money. Montclair: Patterson Smith.

Davidsson, P and Honig, B. 2003. "The Role of Social and human capital among nascent entrepreneurs." Journal of Business Venturing. Vol 18: 301-331.

De Tocqueville, A. 1835/1956. Democracy in America. London: Signet Classics, Penguin,. Economist. Fleecing the flock-The big business of swindling people who trust you

28th January. Available at: http://www.economist.com/node/21543526. 2012.

Fukuyama, F. 1991. Trust: The Social Virtues and the Creation of Prosperity. New York:

Simon Schuster \& Press.

Fukuyama, F. 2001. "Social Capital, civil society and development." Third World Quarterly, $22(1): 7-20$.

Gelles D. and Tett G. 2011. 'From behind bars, Madoff spins his story', The Financial Times. April 8.

Gibbons, D.C. and D. L. Garrity. 1962. "Definition and Analysis of Certain Criminal Types" Journal of Criminal Law and Criminology: Vol 53 (1) March/Spring .

Graeff, P. 2009. "Social capital: The dark side” In G. T. Svendsen \& G. L. H. Svendsen

(Eds.), Handbook of social capital Cheltenham, UK: Edward Elgar: 143-161.

Granovetter, M. 1973. "The Strength of Weak Ties.” American Journal of Sociology. 78:

1360-1380.

Granovetter, M. 1985. "Economic Action and Social Structure: The Problem of

Embeddedness." American Journal of Sociology 91 (3): 481-510.

Granovetter, M. 1992. "Problems of Explanation in Economic Sociology." In, Networks and

Organisations; Structure, Form, and Action, edited by Nitin, N. \& Eccles, R.G, 25-56.

Boston Massachusetts, Harvard Business School Press.

Graeff P. 2009. "Social capital: the dark side.” In: Svendsen, G.T., Svendsen, G.L. (eds.)

Handbook of Social Capital. The Troika of Sociology, Political Science and Economics, Edward Elgar, Cheltenham: 17-35. 
Graeff, P. and G.T. Svendsen, 2013. "Trust and corruption: The influence of positive and negative social capital on the economic development in the European Union." Quality and Quantity, Vol 47, (5): 2829-2846.

Henriques, D.B. 2017. The Wizard of Lies: Bernie Madoff and the Death of Trust. New York, Times Books.

Hirsch, P. M. and Z. Levin. 1999. "Umbrella Advocates Versus Validity Police: A LifeCycle Model.” Organization Science: A Journal of the Institute of Management Sciences. March/April, Vol. 10 (2): 199-212

Hurt, C. 2009. "Evil has a New Name (and a New Narrative): Bernard Madoff" Michigan State Law Review: 947-987.

Jacobs, J. 1961/1993. The Death and Life of Great American Cities. Random House. New York.

Jagpal, N and Craig, J. 2009. "Learning from Madoff: Lessons for foundations Boards." National Committee for Responsive Philanthropy.

Jenssen, I. J. and Greve, A. 2002. "Does the degree of redundancy in social networks influence the success of business start-ups?" International Journal of Entrepreneurial Behaviour and Research. Vol 8 (5): 254-267

Kwon, S. W. and Adler, P.S., 2014. "Social capital: maturation of a field of research. Academy of Management Review, 39, 412-422.

Lewis, L. S. 2012. Con Game: Bernard Madoff and his Victims. London New Brunswick, Lin, N. 1999. 'Social Networks and Status Attainment.' Annual Review of Sociology, 25: 467-487.

Lin, N. 2001. Social Capital, A Theory of Social Structure and Action. Cambridge: Cambridge University Press.

Linstead, S., Maréchal, G. and R. W. Griffin. 2014. "Theorizing and Researching the Dark Side of Organization." Organization Studies 35(2): 165-188

Lee, R. 2008. "Social capital and business and management: Setting a research agenda." International Journal of Management Reviews. Vol 10. (3): 1-27.

Mackay, C. (1852) 1995. Extraordinary Popular Delusions and the Madness of Crowds. Hertfordshire: Wordsworth Reference.

MacKay, M. 2013. Impeccable Connections: The Rise and Fall of Richard Whitney, New York, Black Tower Press.

Manning, P. 2010. "The dark side of social capital: Lessons from the Madoff case". In, W. Sun, J. Stewart \& D. Pollard (Eds.), Reframing corporate social responsibility: Lessons from the global financial crisis. Bingley: Emerald Group Publishing Limited: 207-228.

Markopolos, H. 2010. "No One would Listen: A True Financial Thriller." New York, John Wiley \& Sons.

Messner, S. F. and R Rosenfeld. 2013. Crime and the American Dream. (5th Ed).

Belmont, CA: Wadsworth.

Nahapiet, J. and Ghoshal, S. 1998. "Social Capital, Intellectual Capital and the

Organizational Advantage." Academy of Management Review. 23, (2): 242-266.

Nash, R., Bouchard, M., and A. Malm, 2013. "Investing in people: The role of social networks in the diffusion of a large-scale fraud. Social Networks." 35: 686-698.

10.1016/j.socnet.2013.06.005.

Nash, J.R. 1976. Hustlers and Con Men: An Anecdotal History of the confidence Man and his Games. New York. Evans.

Nash, R., M. Bouchard, \& A Malm. 2013. "Investing in people: The role of social networks in the diffusion of a large-scale fraud." Social Networks Social Networks 35(4): 686-698 Nielsen, R., 2003, "Corruption networks and implications for ethical corruption reform" Journal of Business Ethics, 42(2): 125-149. 
Payne, B. K. 2012. White Collar Crime, The Essentials, London: Sage,

Perri, Frank. S, and R. L. Brody. 2011. "Birds of the same Feather: The Dangers of Affinity Fraud." Journal of Forensic Studies in Accounting and Business, 10 (3): 33-46.

Pillai, K.P., Hodgkinson, G.P., Kalyanaram, G. and S.R. Nair. 2017. "The Negative Effects of Social Capital in Organizations: A Review and Extension." International Journal of Management Reviews, 19, 97-124. DOI: 10.1111/ijmr.12085

Polanyi, K. 1944/2001. The Great Transformation. (2nd Ed). Boston: Beacon Press.

Ponzi, C. The Rise of Mr Ponzi. Accessed 23 February 2015. http://pnzi.com/

Portes, A. 1998. "Social Capital: Its Origins and Applications in Modern Sociology' Annual Review of Sociology', 24 1-24.

Portes, A. 2014. 'Downsides of Social Capital.' Proceedings of the National Academy of Sciences of the United States of America, Vol 111 (52) : 18407-18408

Portes, A., and Sensenbrenner. 1993. "Embeddedness and Immigration: Notes on the Social Determinants of Economic Action.” American Journal of Sociology. 98: 1320-1350.

Portes, A. and Landolt, P., 1996. "The downside of social capital." The American Prospect, 26 (94) : 18-21.

Portes, A. and Vickstrom, E. 2011. "Diversity, social capital and cohesion." Annual Review of Sociology. 37: 461-479.

Putnam, R. D. 1993. Making Democracy Work. Civic Traditions in Modern Italy. Princeton University Press Princeton.

Putnam, R. D. 2000. Bowling Alone. New York: Simon Schuster.

Putnam, R. D. 2004. "Using Social Capital to Help Integrate Planning Theory, Research and Practice." Journal of American Planning Association, 70 : 142-192.

Prusak, D., and Cohen, L. 2001. In Good Company. Boston. Harvard Business School Press. Shibutani, T. 1955. "Reference Groups as Perspectives." In Symbolic Interaction: A Reader in Social Psychology, edited by Manis, J.G. and Meltzer, B.N., (3rd Ed), 105-115.

Massachusetts, Allyn and Bacon.

Shaplen, R., Kreugar, Genius and Swindler. New York, A. A. Knopf, 1961. Accessed at: www.archive.org/.../kreugergeniusand $006788 \mathrm{mbp} / \mathrm{kreugergeniusand006.}$

Schoenheimer, I., MacNeil, K and Madoff, R. 1996. The Great Chefs of America Cook Kosher. New York: Vital Media Enterprises.

Somaiya, R. 2010. 'Bernie Behind Bars: Madoff's Plush Prison Life'. Newsweek, 7th June Smith, G, M Button, L. Johnnston and K. Frimpong. 2011. Studying Fraud as White Collar Crime. London: Palgrave Macmillan.

Stake, Robert E. 1995. The Art of Case Study Research. London, Sage.

Sutherland, E. H. 1939. Principles of Criminology. Philadelphia: J. B. Lippincott.

Sutherland, E. H. 1949. White Collar Crime, New York, Holt.

Sykes, G., and D. Matza. 1957. "Techniques of Neutralization: A Theory of

Delinquency.” American Sociological Review, 22(6): 664-670. Retrieved from http://www.jstor.org/stable/2089195

Uribe, C. A. 2014 "The Dark Side of Social Capital Re-examined from a Policy Analysis Perspective: Networks of Trust and Corruption." Journal of Comparative Policy Analysis: Research and Practice 16: $2: 175-189$.

Uzzi, B. 1996. "The sources and consequences of embeddedness for the economic performance of organisations: the network effect." American Sociological Review, 61, 674698.

Ventura, M., and Daniel, S.J. 2010. "Opportunities for fraud and Embezzlement in Religious Organizations: An Exploratory Study." Journal of Forensic \& Investigative Accounting, 2 (1): 1-35. 
Walters, G.D., and Geyer, M. D. 2004. "Criminal Thinking in identity and in male white collar-crime offenders." Criminal Justice and Behavior, 31 (3) 263-281.

Weinstein, S. 2009. Madoff's Other Secret: Love, Money, Bernie, and Me. St. Martin's Press. New York.

Yin, Robert K. 2002. Applications of Case Study Research, ( $2^{\text {nd }}$ Ed). London, Sage.

Yin, Robert K. 2003. Case Study Research: Design and Methods, (3rd Ed). London, Sage. Zuckoff, M, 2005. Ponzi’s Scheme. New York: Random House. 